\title{
A double-blind controlled trial of the effect of sodium cromoglycate in preventing relapse in ulcerative colitis
}

\author{
P. J. WHORWELL \\ M.D., M.R.C.P. \\ G. M. WHORWELL \\ S.R.N. \\ D. COLIN JONES \\ M.D., F.R.C.P. \\ P. Down \\ A. E. GENT \\ M.D., F.R.C.P. \\ M. D. Hellier \\ M.D., M.R.C.P. \\ G. J. MiLtON-ThOMPSON
M.B., F.R.C.P. \\ M.B. B.S., M.R.C.P. \\ J. BAMFORTH \\ M.B., F.R.C.P. \\ A. EDWARDS \\ M.B., B.Chir. \\ P. GoldING \\ M.B., F.R.C.P. \\ K. R. GOUGH \\ M.D., F.R.C.P. \\ P. ISAACSON \\ D.M., M.R.C.Path. \\ C. A. LOEHRY \\ M.D., F.R.C.P. \\ C. L. SMITH \\ M.D., M.R.C.P. \\ R. P. WALDRAM \\ M.B., M.R.C.P. \\ R. WRIGHT \\ D.Phil., F.R.C.P. \\ Wessex Gastrointestinal Study Group, c/o Professorial Medical Unit, \\ Southampton General Hospital, Southampton SO9 4XY
}

\begin{abstract}
Summary
A double-blind controlled trial of the effect of sodium cromoglycate (SCG) in preventing relapse in ulcerative colitis has been completed in 100 subjects. In patients already taking sulphasalazine, SCG did not prove to be of any additional benefit. However, in patients not on any other maintenance therapy, the relapse rate was $\mathbf{4 0} \%$ for SCG as compared with $\mathbf{7 5} \%$ for placebo. A large study of the effect of SCG in patients intolerant of sulphasalazine is indicated.
\end{abstract}

\section{Introduction}

Following the example of the American National Cooperative Crohn's Disease Study, a group of gastroenterologists has been established in the Wessex area of England to collaborate on controlled therapeutic trials in gastroenterology under the co-ordination of a nurse administrator. Such a trial in ulcerative colitis is now described.

There have been reports that the oral administration of sodium cromoglycate (SCG) is effective in the management of ulcerative proctitis and ulcerative colitis (UC) (Heatley et al., 1975; Mani et al., 1976). More recently, extensive trials have failed to confirm this initial observation, but the dose of SCG and the length of follow-up has been very variable (Buckell et al., 1978; Dronfield and Langman, 1978; Willoughby et al., 1979). The definition of a correct dose may be critical, as there is some evidence that the beneficial effect of SCG in other situations may b\& lost with supramaximal doses (Altounyan, 1979). I was the purpose of this study to assess the effect of SCG alone and in combination with sulphasalazin (SSZ) in preventing relapses in ulcerative colitis.

\section{Patients and methods}

One hundred patients with ulcerative colitis were studied. Patients were eligible for study if they were in remission as defined by being free of symptoms and having a normal sigmoidoscopic appearance granularity being accepted. Subjects must have ha $\Phi$ a relapse within the previous 12 months. Patiento were excluded if they only had proctitis (normal sigmoidoscopic appearances above $15 \mathrm{~cm}$ ) or if the were taking other therapy, such as systemic or loca steroids or antidiarrhoeals.

Those fulfilling the entry criteria were randomld assigned to treatment with SCG $400 \mathrm{mg} 4$ times/day N or placebo. Those already taking SSZ were continued at a standard dose of $0.5 \mathrm{~g} 4$ times/day. Thus thers were 2 groups, those taking SCG alone (Trial 2) and those taking it in combination with SSZ (Trial 1). $\stackrel{0}{+}$

On entry to the study, record was made of pasto medical history, duration and extent of disease, the presence of extra-colonic manifestations, presence of atopy and a family history of inflammatory bowe 
disease (IBD) or atopy. Note was made of past and present medication.

Patients were followed-up at 3-monthly intervals for one year or until a relapse occurred. Rectal biopsies were taken at the beginning, after 6 months and at the end of the study or if a relapse occurred. Relapse was defined as clinical suspicion confirmed by abnormal sigmoidoscopic appearances. Blood was taken for full blood picture, sedimentation rate and biochemical profile at the beginning and end of the study.

Evaluation of therapy was based on the relapse rate and histological comparison of rectal biopsies.

\section{Results}

Table 1 details the characteristics and comparability of the patients in the study. Of 100 patients entered in the trial, complete details for use in Table 1 were available on 93. No adverse reactions to SCG were observed. Sixteen of the 100 patients were withdrawn from the study. Seven patients (3 active, 4 placebo) withdrew because of non-specific side effects. The other 9 patients were withdrawn because of poor compliance.

Table 2 gives details of the relapse rate in the 2 trials for the 84 patients who participated. As can be seen in Trial 1, there was no significant difference between patients on SSZ + SCG and those on SSZ+ placebo. However, in Trial 2 there was a positive trend in favour of SCG, with a relapse rate of $40 \%$ compared with $75 \%$ on placebo, but the numbers were too small to reach statistical significance.

Figure 1 shows the life-table analysis for the 2 trials, and again it can be seen that there is a trend in favour of SCG in those patients who were not additionally taking sulphasalazine. There was no correlation in either of the trials between a history of atopy and a positive response to SCG. In addition, there was no association with response to SCG and extent or duration of disease.

Analysis of rectal biopsies revealed no differences in the severity of inflammation during the course of

TABLE 1. Characteristics of the patients

\begin{tabular}{|c|c|c|c|c|c|c|}
\hline & & \multicolumn{2}{|c|}{ Trial 1} & \multicolumn{2}{|c|}{ Trial 2} & \multirow{2}{*}{$\begin{array}{c}\text { Total no. } \\
(\%)\end{array}$} \\
\hline & & active & placebo & active & placebo & \\
\hline \multicolumn{2}{|l|}{ Mean age (years) } & $43 \cdot 7$ & $46 \cdot 9$ & $41 \cdot 1$ & $43 \cdot 7$ & $43 \cdot 9$ \\
\hline \multicolumn{2}{|l|}{$\begin{aligned} & \text { Sex }: \text { male } \\
& \text { female }\end{aligned}$} & $\begin{array}{l}20 \\
19\end{array}$ & $\begin{array}{l}18 \\
17\end{array}$ & $\begin{array}{l}3 \\
6\end{array}$ & $\begin{array}{l}4 \\
6\end{array}$ & $\begin{array}{l}45(48) \\
48(52)\end{array}$ \\
\hline \multicolumn{2}{|l|}{$\begin{array}{cl}\text { Duration (years) } & 0-5 \\
6-10 & 10\end{array}$} & $\begin{array}{r}25 \\
9 \\
5\end{array}$ & $\begin{array}{r}20 \\
11 \\
4\end{array}$ & $\begin{array}{l}6 \\
2 \\
1\end{array}$ & $\begin{array}{l}5 \\
1 \\
4\end{array}$ & $\begin{array}{l}56(60) \\
23(25) \\
14(15)\end{array}$ \\
\hline $\begin{array}{l}\text { Extent of diseased } \\
\text { colon as measured } \\
\text { from rectum }\end{array}$ & $\begin{array}{l}\text { up to one third } \\
\text { up to two thirds } \\
\text { total }\end{array}$ & $\begin{array}{r}15 \\
13 \\
9\end{array}$ & $\begin{array}{r}22 \\
5 \\
6\end{array}$ & $\begin{array}{l}6 \\
2 \\
1\end{array}$ & $\begin{array}{l}2 \\
4 \\
2\end{array}$ & $\begin{array}{l}45(52) \\
24(28) \\
18(21)\end{array}$ \\
\hline \multicolumn{2}{|c|}{ Extra-intestinal manifestations } & 20 & 13 & 9 & 8 & $50(53)$ \\
\hline \multicolumn{2}{|l|}{ History of atopy } & 8 & 13 & 5 & 5 & $31(33)$ \\
\hline \multicolumn{2}{|l|}{ Family history of atopy } & 15 & 11 & 3 & 6 & $35(37)$ \\
\hline \multicolumn{2}{|c|}{ Family history of inflammatory bowel disease } & 8 & 5 & 4 & 2 & 19 (20) \\
\hline
\end{tabular}

TABLE 2. Relapse rates for Trial 1 (patients taking additional SZP) and Trial 2 (patients taking SCG alone)

\begin{tabular}{llccc}
\hline & & $\begin{array}{c}\text { Total no. of } \\
\text { patients }\end{array}$ & $\begin{array}{c}\text { No. of patients } \\
\text { relapsing (\%) }\end{array}$ & Significance \\
\hline \multirow{2}{*}{ Trial 1 } & Active & 36 & $19(53)$ & NS $^{*}$ \\
& Placebo & 30 & $16(53)$ & \\
Trial 2 & Active & 10 & $4(40)$ & NS $\dagger$ \\
& Placebo & 8 & $6(75)$ & \\
\hline
\end{tabular}

* $\chi^{2}$ test; $†$ Fisher's exact probability test. 
the trial in the treatment or placebo groups. In those patients with tissue eosinophilia who were taking SCG, no significant reduction was observed during the course of the trial when compared with similar subjects taking placebo.

\section{Discussion}

This study fails to show any beneficial effect for SCG in ulcerative colitis in those patients who were already taking sulphasalazine. There was a suggestion that it may be of value in patients who are intolerant of SSZ.
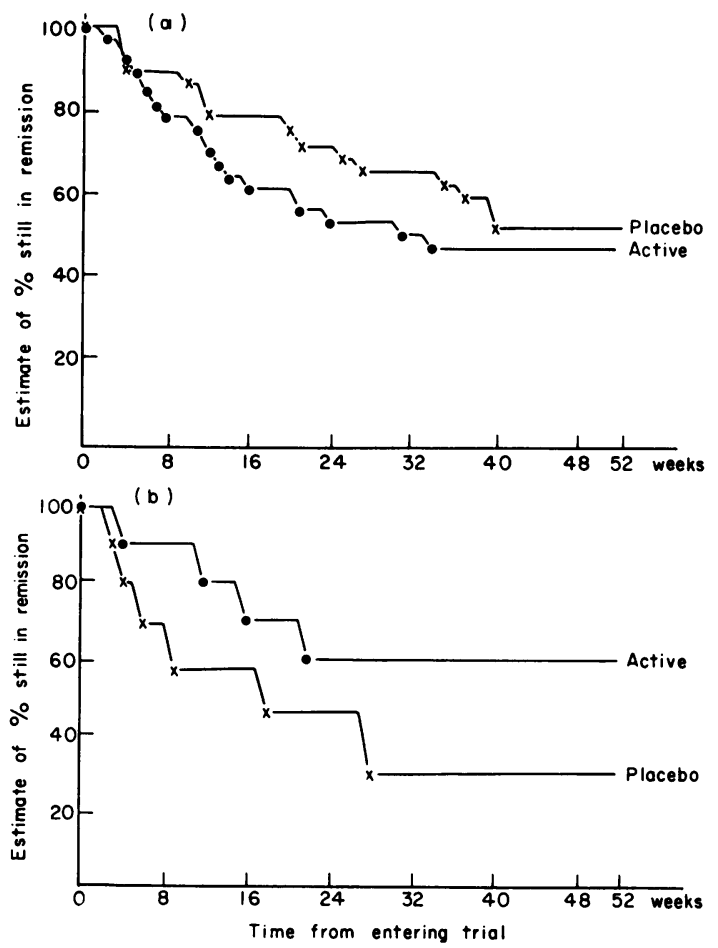

FIG. 1. Life-table analysis of Trial 1(a) and Trial 2(b).

The relapse rate in Trial 1 (those patients additionally taking SSZ) was higher than might be expected for a group of patients taking SSZ (Misiewicz et al., 1965; Dissanayake and Truelove, 1973). The reason for this observation is probably a reflection of the method of selection. Patients had to have had a relapse within one year of starting the trial and therefore probably represented a more unstable subgroup than a group of colitics taken as a whole. The relapse rate for the placebo group in Trial 2 (patients not taking additional SSZ) was approximately as expected (Misiewicz et al., 1965; Dissan- ayake and Truelove, 1973). There was reduction of this value in patients taking SCG.

Comparison of these results with other studies is difficult, as there has been no consistency in terms of dose used, whether patients were in remission of relapse or whether comparison has been with the effect of SSZ or placebo.

One major problem in assessing the efficacy of SCG in ulcerative colitis is that in those patiens taking SSZ it is only ethically justifiable to ado SCG rather than stop SSZ. In this situation, the SSZ may be achieving optimum effect on which SCG cannot improve. SSZ therapy is associated wit a considerable number of adverse reactions, which are to some extent dose-dependent (Azad Kha et al., 1980). However, approximately 10-15\% of. patients are unable to tolerate the drug, even in small doses. The results suggest that a major stud\$ of SCG in this group of patients is warranted, pafo ticularly as SCG is so consistently free of adverse reactions.

\section{Acknowledgments}

We are grateful to Fisons Ltd for financial support. The Wessex Regional Health Authority also provided a grant. Diana Vincent gave valuable assistance at the Royal Ngzvab Hospital, Haslar.

\section{References} and modes of action of sodium cromoglycate. In: The Mag Cell, its Role in Health and Disease, p. 199. Pitman Medico Publishing Co., Tunbridge Wells.

Azad Khan, A.K., Howes, D.T., Piris, J. \& Truelove, S.e. (1980) Optimum dose of sulphasalazine for maintenanc $\bar{E}$ treatment in ulcerative colitis. Gut, 21, 232.

Buckell, N.A., Gould, S.R., Day, D.W., Lennard-Jones; J.E. \& EDWARDS, A.M. (1978) Controlled trial of disodium cromoglycate in chronic persistent colitis. Gut, 19, 1140:

Dissanayake, A.S. \& Truelove, S.C. (1973) A controlled therapeutic trial of long-term maintenance treatment ulcerative colitis with sulphasalazine (Salazopyrin). Gü $14,923$.

Dronfield, M.W. \& LANGman, M.J.S. (1978) Comparative trial of sulphasalazine and oral sodium cromoglycate in the maintenance of remission in ulcerative colitis. Gut, 19, 1136.

Heatley, R.V., Calcraft, B.J., Rhodes, J., Owen, E. \& EvaNS, B.K. (1975) Disodium cromoglycate in the treat ment of chronic proctitis. Gut, 16, 559.

Mani, V., Green, F.H.Y., Lloyd, G., Fox, H. \& Turnberon L.A. (1976) Treatment of ulcerative colitis with oraf disodium cromoglycate. Lancet, i, 439.

Misiewicz, J.J., LenNARD-Jones, J.E., ConNell, A.M Baron, J.H. \& Jones, F.A. (1965) Controlled trial óp sulphasalazine in maintenance therapy for ulceratie colitis. Lancet, i, 185.

Willoughby, C.P., Piris, J., Heyworth, M.F. \& Truelove S.C. (1979) Comparison of disodium cromoglycate an\$ sulphasalazine as maintenance therapy for ulcerative colitis. Lancet, i, 119. 